\title{
IMPACT OF LOCKDOWN DUE TO COVID-19 PANDEMIC ON THE CAREGIVERS' VIOLENT BEHAVIORS TOWARD THEIR CHILDREN
}

\author{
Asmaa Fady Sharif ${ }^{a, b}$
}

${ }^{a}$ Forensic Medicine and Clinical Toxicology Department, Faculty of Medicine, Tanta University, Egypt.

${ }^{\mathrm{b}}$ Clinical Sciences Department, College of Medicine, Dar Al Uloom University, Saudi Arabia.

Corresponding author: Asmaa Fady Sharif

E-mail: dr_asmaafady@yahoo.com

ORCID ID: https://orcid.org/0000-0002-6104-562X

Postal Address: Department of Forensic Medicine \& Clinical Toxicology, Faculty of medicine, Tanta

University, El Geish street, Tanta, Egypt, Postal code: 31527

Phone No.:0096581639317.

Submit Date 2020-08-22

Revise Date 2020-11-09

Accept Date 2020-11-19

\begin{abstract}
Background: The surge of domestic violence during the COVID-19 pandemic is reported as a global phenomenon. Until the present time, no published literature described the situation in the middle east. Aims: The current study aims to examine how the frequency of verbal maltreatment and physical maltreatment may have changed from during the lockdown to postlockdown in a sample of Egyptians living in Saudi Arabia. Methodology: The present study was carried out on 511 Egyptian families residing in Riyadh, the capital city of Saudi Arabia. The study was conducted over 2 phases with more than one month in between the 2 phases. The first phase during the period $10^{\text {th }}$ April- $9^{\text {th }}$ May, while the second phase was carried out during the period $21^{\text {st }}$ June $-20^{\text {th }}$ July when the respondents were requested for a second followup survey. The selection of those dates was based on the lockdown status in Saudi Arabia. During the first phase, the lockdown was almost complete or for more than 16 hours in the day. During the second phase, the lockdown was resolved entirely. Results: The current study revealed that the verbal and physical maltreatment forms were significantly more frequent during the lockdown periods $(\mathrm{p}<0.001)$. The child and the parents' age showed a significant negative correlation with the total physical maltreatment score ( $\mathrm{r}=-0.008,-0.035)$, respectively.

On the other hand, verbal maltreatment was correlated with older children $(r=0.085)$ and older parents $(\mathrm{r}=0.117)$. Conclusion: To conclude, verbal and physical maltreatment are aggravated by the lockdown and quarantine measures associated with the COVID-19 pandemic. The forms of verbal and physical maltreatment didn't differ from those previously reported in the literature. The younger boys of younger parents are more vulnerable to physical maltreatment. It is recommended to pay more attention to preventing child maltreatment, protecting the maltreated child by establishing supporting centers to track and follow such cases.
\end{abstract}

Keywords: COVID-19, Violence, Children, Lockdown, verbal maltreatment, physical maltreatment.

List of abbreviations:

COVID-19: Coronavirus Disease of 2019. R.E.C.: Research Ethical Committee

\section{INTRODUCTION}

COVID-19 pandemic started in Wuhan city, China, and extended to affect humans globally (Cao et al., 2020). Those effects are not limited to the viral infection but extend to the psychological drawbacks. The involved countries reported frequent psychological impairments (Liu et al., 2020). Many governments implemented the lockdown to limit the spread of the disease. Many kinds of literature mentioned the adverse psychological effects of 
COVID-19 in different countries. Verbal and physical maltreatment were frequently associated with stress and abrupt change in the daily routine like the current pandemic (Kantor et al., 2014).

Although there is no clear definition of maltreatment, as it differs according to the cultures and communities, emotional, physical, and sexual maltreatment are examples of well recognized common forms of maltreatment (Guterman, 2008). According to the United Nations Educational Scientific And Cultural Organization, 1.38 billion children were confined to homes due to the implemented quarantine (Brooks et al., 2020). WHO reported the rise of domestic violence hotline calls up to $50 \%$ in many countries. Furthermore, about 92000 child maltreatment reports perceived by one call line in India during the last few months was reported (World Health Organization, 2020).

Different kinds of literature reported increased verbal and physical maltreatment during the lockdown in other countries; in Italy (Mazza et al., 2020), the United States of America (Boserup et al., 2020), Australia, Brazil, and China (van Gelder et al., 2020). Among the middle east, definitive information regarding child maltreatment during the COVID-19 pandemic is lacking; however, previous studies carried out in Africa before the current pandemic revealed that more than $20 \%$ of children are vulnerable to physical and emotional maltreatment in their lives. WHO recommends using population-based surveys as useful tools to track child maltreatment (Meinck et al., 2016).

Several risk factors precipitate the violence associated with the current pandemic; home confinement, schools, and activities closure increase the contact time between the children and the perpetrator, increasing the risk of maltreatment (Wang et al., 2020). Financial instability and business closure and the resultant mental stress enhance the violence tendency among the caregivers. The strict quarantine and social distancing impede the maltreated children's ability to seek support services or ask for health care provider help (Peterman et al., 2020).

The current study is the first study aims to evaluate the verbal and physical maltreatment during the COVID-19 pandemic among the Arabic countries where the studies are limited, and furthermore, to examine how the frequency of the verbal maltreatment and physical maltreatment may have changed from during the lockdown to post-lockdown in a sample of 511 Egyptian families living in Saudi Arabia.

\section{SUBJECTS \& METHODS}

\section{Study design}

The current study is a prospective observational longitudinal study. The aim of the current study to evaluate the situation among the Egyptians living in Saudi Arabia, in which the literature is lacking regarding the effect of the lockdown due to COVID-19 pandemic on the caregiver's violent behaviour (verbal and physical maltreatment), and furthermore, to assess if those forms of maltreatment are different from those reported in the literature.

The present study was carried out on 511 Egyptian families living in Riyadh, the capital city of Saudi Arabia. The study was conducted over 2 phases; the first phase during the period $10^{\text {th }}$ April- $9^{\text {th }}$ May (2020), while the second phase was carried out during the period $21^{\text {st }}$ June $-20^{\text {th }}$ July (2020) when the respondents were requested for a second follow-up survey. With more than one month in between the 2 phases. The selection of those dates was based on the lockdown status in Saudi Arabia. During the first phase, the lockdown was almost complete or for more than 16 hours in the day. During the second phase, the lockdown was resolved entirely.

\section{Participants:}

The study involved 511 Egyptian participants who lived in Saudi Arabia.

Inclusion criteria: The participants should be Egyptian with at least one child aged 18 years old or below. The caregivers 
were regularly live with their children for the last year.

Exclusion criteria: The parents living in other countries and parents living away from their children for the last year were excluded. Participants of different nationalities were excluded as well.

\section{Data Collection and ethical} considerations:

The study was commenced after obtaining the ethical approval number 33828 from the research ethical committee R.E.C. of the Faculty of Medicine, Tanta University, Egypt. For all participants, an online electronic survey generated by google forms was randomly sent via emails. Each participant received a full explanation of the study's aim, risks, and advantages of the study. According to the Helsinki Declaration, there was a statement that declares the respondent informed consent to participate. Furthermore, the respondents had the right to withdraw if they felt any emotional distress while filling the survey. All data were handled anonymously to maintain the confidentiality of the data.

\section{Measurement:}

The survey is divided into four sections; the first section of the survey involved complete demographic data of the participants regarding the age, sex, occupation, residence, employment, marital status, number of family members, and number of children aged less than five years as well. The age and sex of the included child were documented as well.

Following the first section, three sections were addressed: the nonviolent discipline, the verbal maltreatment discipline, and the physical maltreatment discipline. The survey consists of 12 questions about the frequency of different items in each discipline. The questions were scrambled between the various disciplines to prevent biasing the answers. Each question started with the phrase "during the last month.......". The respondents select only one response for each question; never happened, happened once, happened twice, happened 3-5 times, happened 6-10 times and happened more than ten times. For each response, a score was given, and the total score was calculated.

I) The Nonviolent discipline:

- During the last month, how many times did you punish your child by withdrawing the privileges helshe used to practice?

- How many times did you ask your child to stay alone as a punishment during the last month?

\section{II) The verbal maltreatment discipline:}

- During the last month, how many times did you raise your voice or shout at your child as a punishment?

- During the last month, how many times did you impend your child that you will hit him/her as a punishment?

- How many times did you call your child as stupid, idiot, or any other shameful name during the last month?

- The physical maltreatment discipline: During the last month, how many times did you beat your child with your hands out of his her face?

- During the last month, how many times did you bite your child as a punishment?

- How many times did you beat your child with an object rather than your hands during the last month?

- During the last month, how many times did you shake your child vigorously as a punishment?

- How many times did you beat your child with your hands on hislher face

- during the last month?

- How many times did you tie your child's hands or feet as a punishment during the last month?

- How many times did you put hot abject or hot fluid on his/her body as a punishment during the last month?

Statistical Analysis

Statistical analysis was performed using S.P.S.S. Software Package version 26. The Shapiro Wilk test checked the normality of the data. The data were 
presented as means, standard deviation, and percentage. Independent Sample T-test, Chi-square test, Pearson's Chi-square correlations coefficients were used. P values less than 0.05 were considered statistically significant.

\section{RESULTS}

Analysis of the data revealed that the overall reliability of the 12 studied variables using Cronbach's Alpha was 0.805 for the nonviolent discipline, 0.770 for the verbal maltreatment discipline, and 0.823 for the physical maltreatment discipline. $89 \%$. The respondents (511) were mostly females (475) $93 \%$ in comparison to (36) $7 \%$ males. Regarding the children involved in the current study, the girls constituted (225) $44 \%$ while the boys were (286) $56 \%$.

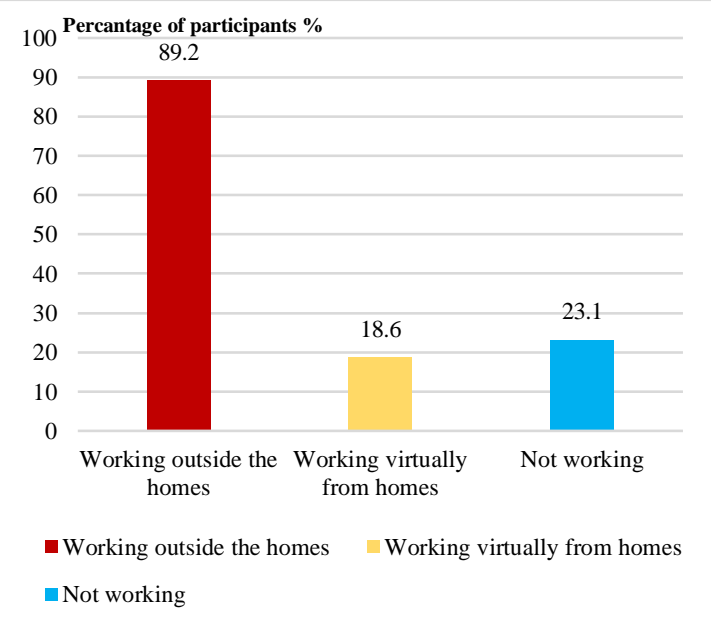

Figure (1): Employment status of the participants included in the study during the lockdown period.

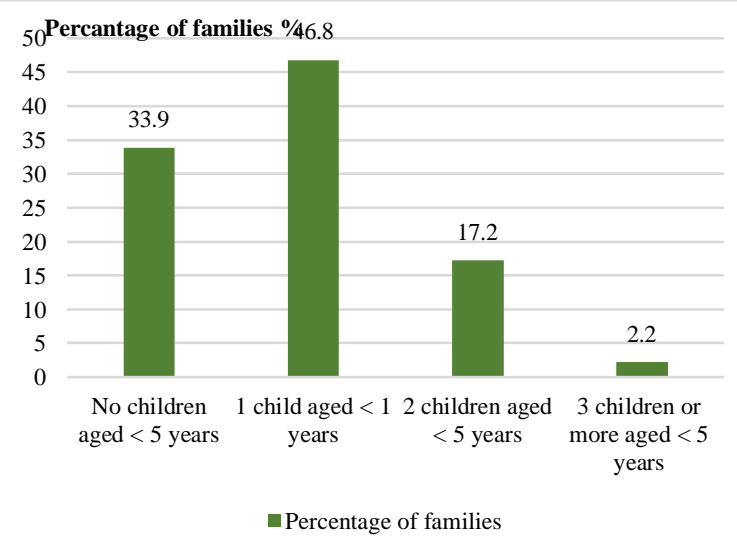

Figure (2): Percentage of families included in the study according to the number of children less than 5 years old.
Fig. 1 and Fig. 2 depict some of the participant's demographics. Most of the participants (456), 89.2\% lived regular marital life, seven divorced, seven widowed, and two separated participants. Among the participants, 53.6\% (274) have bachelor, and (237) $46.4 \%$ earned postgraduate studies as well. Analysis of the employment status of the participants showed that during the lockdown, the proportion of those not working raised to $58.3 \%$ compared with $18.6 \%$ working virtually from homes and $23.1 \%$ working outside.

For the families involved in the current study, the mean number of the whole family members was $(4.53 \pm 2.893)$. The mean number of children (less than 18 years old) was $(2.47 \pm 1.013$ years $)$. The majority of those families $(96.5 \%)$ have four or fewer children, while only 18 families $(3.5 \%)$ have five children or more. $33.9 \%$ of the included families don't have children less than five years, compared to $46.8 \%$ families have one child less than five years old and $17.2 \%$ have two children less than five years old, and only 11 families $(2.2 \%)$ have three children or more aged less than five years old.

Table 1 and Table 2 show that, except for tying the limbs and intentional burning, the means of the different violent items among the different disciplines were increased during the lockdown period when compared with the period after $(\mathrm{p}<0.05)$. When the total score of each discipline was calculated, the nonviolent discipline, as well as the verbal and physical maltreatment disciplines showed significantly higher scores during the lockdown periods in comparison to the period after $(\mathrm{p}<0.001)$.

Table 3. The mean total score of verbal maltreatment was $(13.3386 \pm 12.06603)$ and $(10.1115 \pm 10.54130)$ during the lockdown and after consecutively. The mean total score of physical maltreatment during the lockdown period and after was $(4.9080 \pm 8.77124)$ and $(4.0333 \pm 7.65179)$ simultaneously. Furthermore, A significant 
strong positive correlation was observed between the total score of verbal maltreatment and the lockdown $(\mathrm{r}=0.725)$ and between the total score of the physical maltreatment and the lockdown $(r=0.792)$. When the different items were coded as dichotomous variables with the responses
(Yes, No), during the lockdown period, the majority of the participants, $96 \%$, practiced the shouting, threatening with hitting $67.7 \%$, and slapping out of the face $59.0 \%$. Tying the limbs and intentional burning was less frequent as only $0.2 \%$, and $0.4 \%$ consecutively practiced that Table 4 .

Table (1): Description of the violent and nonviolent disciplines during and After the lockdown due to COVID-19 pandemic

\begin{tabular}{|c|c|c|c|c|}
\hline Discipline & Time period & Mean & $\begin{array}{c}\text { Std. } \\
\text { Deviation }\end{array}$ & $\begin{array}{c}\text { Std. Error } \\
\text { Mean }\end{array}$ \\
\hline \multicolumn{5}{|c|}{ The Nonviolent discipline: } \\
\hline \multirow{2}{*}{$\begin{array}{l}\text { How many times did you punish } \\
\text { your child by withdrawing the } \\
\text { privileges helshe used to practice? }\end{array}$} & During the lockdown & 3.44 & 4.222 & 0.187 \\
\hline & After the lockdown & 3.04 & 3.703 & 0.164 \\
\hline \multirow{2}{*}{$\begin{array}{l}\text { How many times did you ask your } \\
\text { child to stay alone as a punishment? }\end{array}$} & During the lockdown & 0.51 & 1.695 & 0.075 \\
\hline & After the lockdown & 0.45 & 1.618 & 0.072 \\
\hline \multicolumn{5}{|c|}{ The verbal maltreatment discipline: } \\
\hline \multirow{2}{*}{$\begin{array}{l}\text { How many times did you raise your } \\
\text { voice or shout on your child as a } \\
\text { punishment? }\end{array}$} & During the lockdown & 7.25 & 5.817 & 0.257 \\
\hline & After the lockdown & 5.63 & 5.590 & 0.247 \\
\hline \multirow{2}{*}{$\begin{array}{l}\text { How many times did you impend } \\
\text { your child that you will hit him as a } \\
\text { punishment? }\end{array}$} & During the lockdown & 4.26 & 5.323 & 0.235 \\
\hline & After the lockdown & 3.33 & 4.748 & 0.210 \\
\hline \multirow{2}{*}{$\begin{array}{l}\text { How many times did you call your } \\
\text { child as stupid, idiot or any other } \\
\text { shameful name? }\end{array}$} & During the lockdown & 1.83 & 3.620 & 0.160 \\
\hline & After the lockdown & 1.15 & 2.707 & 0.120 \\
\hline \multicolumn{5}{|c|}{ The physical maltreatment discipline: } \\
\hline \multirow{2}{*}{$\begin{array}{l}\text { How many times did you beat your } \\
\text { child with your hands out of hislher } \\
\text { face? }\end{array}$} & During the lockdown & 2.42 & 3.812 & 0.169 \\
\hline & After the lockdown & 1.89 & 3.354 & 0.148 \\
\hline \multirow{2}{*}{$\begin{array}{l}\text { How many times did you bite your } \\
\text { child as a punishment? }\end{array}$} & During the lockdown & 0.76 & 2.422 & 0.107 \\
\hline & After the lockdown & 0.62 & 1.943 & 0.086 \\
\hline \multirow{2}{*}{$\begin{array}{l}\text { How many times did you beat your } \\
\text { child with an object rather than } \\
\text { your hands? }\end{array}$} & During the lockdown & 0.55 & 1.996 & 0.088 \\
\hline & After the lockdown & 0.47 & 1.523 & 0.067 \\
\hline \multirow{2}{*}{$\begin{array}{c}\text { How many times did you shake } \\
\text { your child vigorously as a } \\
\text { punishment? }\end{array}$} & During the lockdown & 0.64 & 1.834 & 0.081 \\
\hline & After the lockdown & 0.45 & 1.529 & 0.068 \\
\hline \multirow{2}{*}{$\begin{array}{l}\text { How many times did you beat your } \\
\text { child with your hands on histher } \\
\text { face? }\end{array}$} & During the lockdown & 0.54 & 1.728 & 0.076 \\
\hline & After the lockdown & 0.54 & 1.730 & 0.077 \\
\hline \multirow{2}{*}{$\begin{array}{l}\text { How many times did you tie your } \\
\text { child hands or feet as a } \\
\text { punishment? }\end{array}$} & During the lockdown & 0.00 & 0.044 & 0.002 \\
\hline & After the lockdown & 0.02 & 0.367 & 0.016 \\
\hline \multirow{2}{*}{$\begin{array}{l}\text { How many times did you put hot } \\
\text { abject or hot fluid on his/her body } \\
\text { as a punishment? }\end{array}$} & During the lockdown & 0.00 & 0.062 & 0.003 \\
\hline & After the lockdown & 0.03 & 0.665 & 0.029 \\
\hline
\end{tabular}

Number of cases 511. 
Table (2): Comparison of violent and nonviolent disciplines during and After the lockdown due to COVID-19 pandemic

\begin{tabular}{|c|c|c|c|c|c|c|}
\hline \multirow{3}{*}{ Discipline } & \multicolumn{4}{|c|}{$\begin{array}{c}\text { Paired differences (during and After the } \\
\text { lockdown) }\end{array}$} & \multirow{3}{*}{$\begin{array}{c}\text { T- } \\
\text { value }\end{array}$} & \multirow{3}{*}{$\begin{array}{c}\text { P- } \\
\text { value }\end{array}$} \\
\hline & \multirow[t]{2}{*}{ Mean } & \multirow{2}{*}{$\begin{array}{c}\text { Std. } \\
\text { Deviati } \\
\text { on }\end{array}$} & \multicolumn{2}{|c|}{$\begin{array}{l}\text { 95\% Confidence Interval } \\
\text { of the Difference }\end{array}$} & & \\
\hline & & & Lower & Upper & & \\
\hline \multicolumn{7}{|c|}{ The Nonviolent discipline: } \\
\hline $\begin{array}{l}\text { How many times did you punish your } \\
\text { child by withdrawing the privileges } \\
\text { helshe used to practice? }\end{array}$ & 0.403 & 3.389 & 0.109 & 0.698 & 2.689 & $0.007 *$ \\
\hline $\begin{array}{l}\text { How many times did you impend } \\
\text { your child that you will hit him as a } \\
\text { punishment? }\end{array}$ & 0.061 & 1.322 & -0.054 & 0.176 & 1.037 & 0.300 \\
\hline \multicolumn{7}{|c|}{ The verbal maltreatment discipline: } \\
\hline $\begin{array}{l}\text { How many times did you raise your } \\
\text { voice or shout on your child as a } \\
\text { punishment? }\end{array}$ & 1.616 & 4.726 & 1.206 & 2.027 & 7.732 & $\begin{array}{l}<0.001 \\
* *\end{array}$ \\
\hline $\begin{array}{l}\text { How many times did you impend } \\
\text { your child that you will hit him as a } \\
\text { punishment? }\end{array}$ & 0.926 & 4.134 & 0.566 & 1.285 & 5.062 & $\begin{array}{l}<0.001 \\
* *\end{array}$ \\
\hline $\begin{array}{l}\text { How many times did you call your } \\
\text { child as stupid, idiot or any other } \\
\text { shameful name? }\end{array}$ & 0.685 & 2.833 & 0.439 & 0.931 & 5.465 & $\begin{array}{c}<0.001 \\
* *\end{array}$ \\
\hline \multicolumn{7}{|c|}{ The physical maltreatment discipline: } \\
\hline $\begin{array}{l}\text { How many times did you beat your } \\
\text { child with your hands out of his ther } \\
\text { face? }\end{array}$ & 0.528 & 2.932 & 0.274 & 0.783 & 4.074 & $\begin{array}{l}<0.001 \\
* *\end{array}$ \\
\hline $\begin{array}{l}\text { How many times did you bite your } \\
\text { child as a punishment? }\end{array}$ & 0.135 & 1.435 & 0.010 & 0.260 & 2.128 & $0.034 *$ \\
\hline $\begin{array}{l}\text { How many times did you beat your } \\
\text { child with an object rather than your } \\
\text { hands? }\end{array}$ & 0.074 & 1.808 & -0.083 & 0.231 & .930 & 0.353 \\
\hline $\begin{array}{l}\text { How many times did you shake your } \\
\text { child vigorously as a punishment? }\end{array}$ & 0.184 & 1.542 & 0.050 & 0.318 & 2.697 & $0.007 *$ \\
\hline $\begin{array}{l}\text { How many times did you beat your } \\
\text { child with your hands on histher } \\
\text { face? }\end{array}$ & 0.000 & 1.732 & -0.151 & 0.151 & 0.000 & 1.000 \\
\hline $\begin{array}{l}\text { How many times did you tie your } \\
\text { child hands or feet as a punishment? }\end{array}$ & -0.020 & 0.365 & -0.051 & 0.012 & -1.213 & 0.226 \\
\hline $\begin{array}{l}\text { How many times did you put hot } \\
\text { abject or hot fluid on his/her body as } \\
\text { a punishment? }\end{array}$ & -0.027 & 0.665 & -0.085 & 0.030 & -0.931 & 0.352 \\
\hline
\end{tabular}

Paired Sample T-test, Degree of freedom 510, Number of cases 511.

$*$ Significance $<0.05$ 
Table (3): Comparison of the total scores of nonviolent, verbal and physical maltreatment disciplines during and after the lockdown due to COVID-19 pandemic

\begin{tabular}{|c|c|c|c|c|c|c|c|}
\hline \multirow{3}{*}{$\begin{array}{c}\text { Discipline } \\
\text { (Total score) }\end{array}$} & \multicolumn{5}{|c|}{ Paired Differences during and After the lockdown } & \multirow{3}{*}{$\mathbf{t}$} & \multirow{3}{*}{ P-value } \\
\hline & \multirow[t]{2}{*}{ Mean } & \multirow[t]{2}{*}{$\begin{array}{c}\text { Std. } \\
\text { Deviation }\end{array}$} & \multirow[t]{2}{*}{$\begin{array}{l}\text { Std. } \\
\text { Error } \\
\text { Mean }\end{array}$} & \multicolumn{2}{|c|}{$\begin{array}{l}95 \% \text { Confidence } \\
\text { Interval of the } \\
\text { Difference }\end{array}$} & & \\
\hline & & & & Lower & Upper & & \\
\hline The nonviolent discipline & 0.480 & 5.776 & 0.115 & 0.254 & 0.707 & 4.166 & $<0.001 * *$ \\
\hline The verbal maltreatment & 3.227 & 8.501 & 0.376 & 2.488 & 3.966 & 8.581 & $<0.001 * *$ \\
\hline The physical maltreatment & 0.875 & 5.400 & 0.239 & 0.405 & 1.344 & 3.662 & $<0.001 * *$ \\
\hline
\end{tabular}

Paired Samples T-test, Number of cases 511 Significance $<0.05$

Table (4): Frequencies of maltreatment during the lockdown due to COVID-19 pandemic

\begin{tabular}{|c|c|c|c|}
\hline Have you ever ......... ? & \multicolumn{2}{|c|}{ Responses (511) } & Percent \\
& Yes cases \\
\cline { 2 - 3 } & 461 & $27.8 \%$ & $96.0 \%$ \\
\hline Raised your voice or shout on your child as a punishment? & 325 & $19.6 \%$ & $67.7 \%$ \\
\hline Impended your child that you will hit him as a punishment? & 200 & $12.1 \%$ & $41.7 \%$ \\
\hline Called your child as stupid, idiot or any other shameful name? & 283 & $17.1 \%$ & $59.0 \%$ \\
\hline Beat your child with your hands out of his hher face? & 101 & $6.1 \%$ & $21.0 \%$ \\
\hline Bit your child as a punishment? & 74 & $4.5 \%$ & $15.4 \%$ \\
\hline Beat your child with an object rather than your hands? & 115 & $6.9 \%$ & $24.0 \%$ \\
\hline Shaken your child vigorously as a punishment? & 95 & $5.7 \%$ & $19.8 \%$ \\
\hline Beat your child with your hands on hislher face? & 1 & $0.1 \%$ & $0.2 \%$ \\
\hline Tied your child hands or feet as a punishment? & 2 & $0.1 \%$ & $0.4 \%$ \\
\hline Put hot abject or hot fluid on his/her body as a punishment? & 1657 & $100.0 \%$ & $345.2 \%$ \\
\hline Total & &
\end{tabular}

Table 5 shows that the sex of the child influenced the frequency of maltreatment. The boys were more vulnerable to be injured, both verbally and physically, except for tying and intentional burning. Independent sample T-test showed that during the lockdown period, the boys showed highly significant verbal and physical maltreatment total scores than the girls ( $\mathrm{p}<0.001)$. Regarding the perpetrator, during the lockdown, and among the different maltreatment items, shouting and beating out of the face were significantly practiced more by the mothers ( $\mathrm{p}<0.05)$, as $90.9 \%$ of the mothers practiced shouting in comparison to $80.6 \%$ of fathers. $56.6 \%$ of mothers reported beating the children with hands in areas other than the face, in contrast to $38.9 \%$ of the fathers. On the other hand, the shaking was significantly common among the fathers $(\mathrm{p}<0.05)$; $36.1 \%$ of fathers practiced shaking once or more in comparison to $21.5 \%$ of mothers (Table 6). 
Table (5): Distribution of verbal and physical maltreatment according to the sex of children during the lockdown due to COVID-19 pandemic

\begin{tabular}{|c|c|c|c|c|c|c|}
\hline \multirow[t]{2}{*}{ Have you ever.......? } & \multirow{2}{*}{\multicolumn{2}{|c|}{ Sex of the child }} & \multicolumn{2}{|c|}{$\begin{array}{l}\text { Response of the } \\
\text { caregivers }\end{array}$} & \multicolumn{2}{|c|}{$\begin{array}{l}\text { Pearson's Chi- } \\
\text { Square }\end{array}$} \\
\hline & & & No & Yes & $\chi$ & P-value \\
\hline \multirow{3}{*}{$\begin{array}{c}\text { Raised your voice or shout } \\
\text { on your child as a } \\
\text { punishment? }\end{array}$} & Girls & (\% within the group) & $4.8 \%$ & $95.2 \%$ & \multirow{3}{*}{7.215} & \multirow{3}{*}{$0.007 *$} \\
\hline & Boys & (\% within the group) & $2.8 \%$ & $97.2 \%$ & & \\
\hline & & Total & $3.6 \%$ & $96.4 \%$ & & \\
\hline \multirow{3}{*}{$\begin{array}{l}\text { Impended your child that you } \\
\text { will hit him as a punishment? }\end{array}$} & Girls & (\% within the group) & $12.7 \%$ & $87.3 \%$ & \multirow{3}{*}{44.002} & \multirow{3}{*}{$<0.001^{* *}$} \\
\hline & Boys & (\% within the group) & $5.3 \%$ & $94.7 \%$ & & \\
\hline & & Total & $8.4 \%$ & $91.6 \%$ & & \\
\hline \multirow{3}{*}{$\begin{array}{c}\text { Called your child as stupid, } \\
\text { idiot or any other shameful } \\
\text { name? }\end{array}$} & Girls & (\% within the group) & $45.3 \%$ & $54.7 \%$ & \multirow{3}{*}{6.087} & \multirow{3}{*}{$0.014 *$} \\
\hline & Boys & (\% within the group) & $40.4 \%$ & $59.6 \%$ & & \\
\hline & & Total & $42.5 \%$ & $57.5 \%$ & & \\
\hline \multirow{3}{*}{$\begin{array}{l}\text { Beat your child with your } \\
\text { hands out of hislher face? }\end{array}$} & Girls & (\% within the group) & $4.7 \%$ & $95.3 \%$ & \multirow{3}{*}{6.101} & \multirow{3}{*}{$0.014^{*}$} \\
\hline & Boys & (\% within the group) & $2.8 \%$ & $97.2 \%$ & & \\
\hline & & Total & $3.6 \%$ & $96.4 \%$ & & \\
\hline \multirow{3}{*}{$\begin{array}{l}\text { Bit your child as a } \\
\text { punishment? }\end{array}$} & Girls & (\% within the group) & $51.2 \%$ & $48.8 \%$ & \multirow{3}{*}{34.541} & \multirow{3}{*}{$<0.001 * *$} \\
\hline & Boys & (\% within the group) & $39.4 \%$ & $60.6 \%$ & & \\
\hline & & Total & $44.4 \%$ & $55.6 \%$ & & \\
\hline \multirow{3}{*}{$\begin{array}{c}\text { Beat your child with an } \\
\text { object rather than your } \\
\text { hands? }\end{array}$} & Girls & (\% within the group) & $61.6 \%$ & $38.4 \%$ & \multirow{3}{*}{38.057} & \multirow{3}{*}{$<0.001 * *$} \\
\hline & Boys & (\% within the group) & $49.2 \%$ & $50.8 \%$ & & \\
\hline & & Total & $54.5 \%$ & $45.5 \%$ & & \\
\hline \multirow{3}{*}{$\begin{array}{c}\text { Shaken your child vigorously } \\
\text { as a punishment? }\end{array}$} & Girls & (\% within the group) & $56.9 \%$ & $43.1 \%$ & \multirow{3}{*}{51.990} & \multirow{3}{*}{$<0.001 * *$} \\
\hline & Boys & (\% within the group) & $42.4 \%$ & $57.6 \%$ & & \\
\hline & & Total & $48.5 \%$ & $51.5 \%$ & & \\
\hline \multirow{3}{*}{$\begin{array}{l}\text { Beat your child with your } \\
\text { hands on his her face? }\end{array}$} & Girls & (\% within the group) & $51.5 \%$ & $48.5 \%$ & \multirow{3}{*}{34.530} & \multirow{3}{*}{$<0.001 * *$} \\
\hline & Boys & (\% within the group) & $39.7 \%$ & $60.3 \%$ & & \\
\hline & & Total & $44.7 \%$ & $55.3 \%$ & & \\
\hline \multirow{3}{*}{$\begin{array}{c}\text { Tied your child hands or feet } \\
\text { as a punishment? }\end{array}$} & Girls & (\% within the group) & $100 \%$ & $0 \%$ & \multirow{3}{*}{5.164} & \\
\hline & Boys & (\% within the group) & $99.5 \%$ & $0.5 \%$ & & $0.023 *$ \\
\hline & & Total & $99.7 \%$ & $0.3 \%$ & & \\
\hline Put hot abject or hot fluid on & Girls & (\% within the group) & $98.2 \%$ & $1.8 \%$ & & \\
\hline his/her body as a & Boys & (\% within the group) & $100 \%$ & $0 \%$ & 26.025 & $<0.001 * *$ \\
\hline punishment? & & Total & $99.2 \%$ & $0.8 \%$ & & \\
\hline
\end{tabular}

Pearson Chi-Square correlations

Number of cases $511 \mathrm{df}=1 *$ significance $<0.05$ 
Table (6): Distributions of the verbal and physical maltreatment showing significant differences regarding the sex of the parent during the lockdown due to COVID-19 pandemic

\begin{tabular}{|c|c|c|c|c|c|c|}
\hline \multirow{2}{*}{ Have you ever.......? } & \multirow{2}{*}{\multicolumn{2}{|c|}{ Sex of the perpetrator }} & \multicolumn{2}{|c|}{ Response } & \multicolumn{2}{|c|}{$\begin{array}{l}\text { Pearson Chi- } \\
\text { Square }\end{array}$} \\
\hline & & & No & Yes & $\chi$ & $\begin{array}{c}\text { P- } \\
\text { value }\end{array}$ \\
\hline \multirow{3}{*}{$\begin{array}{l}\text { Raised your voice or } \\
\text { shout on your child } \\
\text { as a punishment? }\end{array}$} & Mother & $\begin{array}{c}\text { Count } \\
\text { (\% within the group) }\end{array}$ & $\begin{array}{c}43 \\
(9.1 \%)\end{array}$ & $\begin{array}{c}432 \\
(90.9 \%)\end{array}$ & \multirow[b]{2}{*}{4.094} & \multirow{2}{*}{$0.043 *$} \\
\hline & Father & $\begin{array}{c}\text { Count } \\
\text { (\% within the group) }\end{array}$ & $\begin{array}{c}7 \\
(19.4 \%)\end{array}$ & $\begin{array}{c}29 \\
(80.6 \%) \\
\end{array}$ & & \\
\hline & & Total & $\begin{array}{c}50 \\
(9.8 \%) \\
\end{array}$ & $\begin{array}{c}461 \\
(90.2 \%) \\
\end{array}$ & & \\
\hline \multirow{3}{*}{$\begin{array}{l}\text { Beat your child with } \\
\text { your hands out of } \\
\text { histher face? }\end{array}$} & Mother & $\begin{array}{c}\text { Count } \\
\text { (\% within the group) }\end{array}$ & $\begin{array}{c}206 \\
(43.4 \%) \\
\end{array}$ & $\begin{array}{c}269 \\
(56.6 \%) \\
\end{array}$ & \multirow{2}{*}{4.263} & \multirow{2}{*}{$0.039 *$} \\
\hline & Father & $\begin{array}{c}\text { Count } \\
\text { (\% within the group) }\end{array}$ & $\begin{array}{c}22 \\
(61.1 \%) \\
\end{array}$ & $\begin{array}{c}14 \\
(38.9 \%) \\
\end{array}$ & & \\
\hline & & Total & $\begin{array}{c}228 \\
(44.6 \%) \\
\end{array}$ & $\begin{array}{c}283 \\
(55.4 \%) \\
\end{array}$ & & \\
\hline \multirow{3}{*}{$\begin{array}{l}\text { Shaken your child } \\
\text { vigorously as a } \\
\text { punishment? }\end{array}$} & Mother & $\begin{array}{c}\text { Count } \\
\text { (\% within the group) }\end{array}$ & $\begin{array}{c}373 \\
(78.5 \%)\end{array}$ & $\begin{array}{c}102 \\
(21.5 \%)\end{array}$ & \multirow{2}{*}{4.111} & \multirow{2}{*}{$0.043 *$} \\
\hline & Father & $\begin{array}{c}\text { Count } \\
\text { (\% within the group) }\end{array}$ & $\begin{array}{c}23 \\
(63.9 \%)\end{array}$ & $\begin{array}{c}13 \\
(36.1 \%)\end{array}$ & & \\
\hline & & Total & $\begin{array}{c}396 \\
(77.5 \%)\end{array}$ & $\begin{array}{c}115 \\
(22.5 \%)\end{array}$ & & \\
\hline
\end{tabular}

Number of cases $511, *$ significance $<0.05$.

During the lockdown period, analysis of the demographic data revealed that the age of the child and the age of the parents showed a significant negative correlation with the total physical maltreatment score; the younger the child and/or the parents, the more frequent physical maltreatment $(\mathrm{r}=-$ $0.008)$ for the child age and $(r=-0.035)$ for the parent's age. On the other hand, verbal maltreatment was correlated with older children's ages $(r=0.085)$ and among older parents as well $(\mathrm{r}=0.117)$.

\section{DISCUSSION}

The current study emphasized the increasing violent behaviors among Egyptian caregivers living in Saudi Arabia during the lockdown due to the COVID-19 pandemic. This was obvious when the frequency of the different verbal and physical maltreatment behaviors was compared during the lockdown and after. Although the surge of maltreatment was reported in different countries, no published literature described the situation in the middle east until the present time and up to our knowledge. Underreporting of this serious issue among the conservative Arabic countries was reported in previous studies (Alsehaimi, 2015).

The Guardian mentioned that the rise of domestic violence during the COVID-19 pandemic is a global phenomenon (Graham-Harrison et al., 2020). In China, the first country reported the appearance of the COVID-19 pandemic in Wuhan city. The first country conducted a lockdown system; the studies conducted reported a rise in domestic violence up to 3 times compared to the last year (AllenEbrahimian, 2020). The situation was not limited to China; in New Zealand, Brazil, Spain, and the United Kingdom, the governments reported that domestic violence, particularly child maltreatment, has risen by $20 \%-50 \%$ of the baseline (Usher et al., 2020). A previous study conducted in France revealed a rise in domestic violence reports, including child maltreatment, by $30 \%$ when the country implemented the lockdown. Argentina and 
Singapore reported a similar increased rate (25\%, 33\%), respectively (Women, 2020). The reports from the United States of America documented a rise in domestic violence-related murder in lockdownimplemented states (Boserup et al., 2020). The situation in Australia partially agreed to the noticed violence surge during the lockdown. Although it was reported that crimes decreased by $40 \%$ following the lockdown, but the domestic violence calls increased by $5 \%$ (Usher et al., 2020)

On the other hand, a previous study conducted in India reported improvement in family bonding during the lockdown. However, this was only among the moderate level, not in the low or high levels (Ragamayi, 2020). This might be explained by the different nature of the studies; the study conducted in India was based on the emotional family bonding as the respondents express rather than on specified acts or maltreatment items.

Many kinds of literature justified the rise in violent behaviors during the COVID19 pandemic; Bradbury et al. attributed that to the associated stress and fear of being infected. Furthermore, underreporting for fear of getting the infection during the counseling session, unavailable shuttling, and inability to report the maltreatment to encourage the perpetrator to practice their violence without considering the legal responsibility (Bradbury-Jones and Isham, 2020). The isolation and social confinement to homes for prolonged periods as what had happened during the lockdown is another risk factor. Children confined to homes are 60 times more vulnerable to be maltreated compared to the children practicing their usual outdoor activities. Staying at homes for longer periods prolongs the contact time between the child and the abuser and, hence, more maltreatment (Campbell, 2020).

In Australia, alcohol sales rose up to $36 \%$ during the lockdown (Usher et al., 2020). Mental illness, illicit drug abuse, and excessive alcohol consumption were reported as common precipitating factors of domestic violence (Gulati and Kelly, 2020; Peterman et al., 2020). The financial and economic crisis, business closure, and closure of most workplaces are considered another risk factor that might predispose the maltreatment behaviors. Domestic violence was reported to be frequently practiced among families on low income compared to families on higher incomes (Douglas et al., 2020). Peterman et al. attributed the violence and aggression to the virusspecific source (Peterman et al., 2020). Moreover, previous studies mentioned that the abusers used COVID-19 as a coercive mechanism to inflict more control over their victims (Usher et al., 2020).

The current study showed that verbal maltreatment was the most frequently encountered form of maltreatment. About $96 \%$ of the families included in the current study practiced the different verbal maltreatment items. This was similarly reported in different countries; a previous study conducted among the Saudi populations showed that about $74.9 \%$ of the cases included in a study underwent verbal maltreatment (Al-Eissa et al., 2015). Similarly, a former study conducted in Egypt revealed that shouting (72\%), threatening, and calling the children with unpopular names $(51 \%)$ were the most common maltreatment items practiced by the Egyptian mothers (Bangdiwala et al., 2004). Although common, those percentages vary among different countries. In Philippine and Chile, less frequent calling the children with shameful names but more frequent shouting were reported (Krug et al., 2002).

Regarding the physical maltreatment, or what is called "corporal punishment" in many kinds of literature, it was frequently reported in Egypt and among the Arabic populations. (Elbendary radwan et al., 2019; Zaghloul et al., 2020). Many authors blame the cultures in such countries that consider physical maltreatment as an acceptable form of children punishment (Karthikeyan et al., 2000). In agreement with the current study, widespread physical 
maltreatment was reported in a previous study conducted in Saudi Arabia; they mentioned that about $48.9 \%$ of maltreatment activities were in among the physical form, with resultant $0.25 \%-8.3 \%$ fatalities (Almuneef and Al-Eissa, 2011; Al Eissa and Almuneef, 2010).

The current study revealed that beating the children with hands or with hard objects were fair common. This went hand in hand with a previous study conducted in Egypt and revealed that about $71 \%$ of families practiced beating their children with hands and $25 \%$ of families used to beat their children with hard objects (Youssef et al., 1998). This percentage is a little bit higher than the current study, which might be attributed to the time elapsed between the current study and the mentioned study, and furthermore, to the difference in the habits between Egyptians living inside and outside Egypt. Concerning slapping on the face, the current study revealed that $19.8 \%$ of the parents practiced that. This percentage was less than the percentage reported previously in another study conducted in Egypt. They said that about $41 \%$ of Egyptian children suffered slapping on the face (Pro, 2002). Besides, a study conducted among the dental physicians in Saudi Arabia highlighted the frequent presentation of children with dental trauma due to physical maltreatment in the form of facial slapping (Al-Dabaan et al., 2014).

Regarding the biting and disparity with the frequent biting reported in the current study $(55.6 \%)$, a previous study conducted in Saudi Arabia mentioned that only 1.9\% of the reported maltreatment forms were presented to the hospital biting (Almuneef and Al-Eissa, 2011). This could be explained by the different data collection sources between the two studies. The current study was built on the caregiver's responses. In contrast, the study conducted in Saudi Arabia was based on the findings among the cases presented to the hospitals, in which the biting as an isolated finding would be mostly underreported.
Moreover, and in agreement with the current study, the significant rise of physical maltreatment like beating among the mothers compared to the fathers was supported by previous studies (Hunter et al., 2000). However, and regarding the shaking, the current study showed that it was significantly more frequent among the fathers. This was supported by previous research (Pro, 2002). The males' strong bodybuilt could justify it compared with the females, hence their tendency to practice severe violent forms like shaking (Klevens et al., 2000).

On the other side of the coin, the current study illustrated that tying the children's limbs to restrict their movement and intentional burning were the least frequently reported maltreatment forms. Those forms of maltreatment (tying the limbs and intentional burning) were practiced among $0.2 \%$ and $0.1 \%$ of the participants, respectively. These findings agreed with a previous study conducted in Egypt by Youssef et al., who mentioned that $0.37 \%$ of the parents included in their study used to tie their children as a punishment. The occasional use of intentional burning as punishment went hand in hand with previous studies conducted in 4 different countries, Chile, India, the Philippines, and the United States (Tang, 1998).

Regarding the child's age, the current study revealed that the younger the age of the child, the more frequent physical maltreatment. This was in agreement with previous studies (Adinkrah, 2000). Furthermore, and in agreement with the current study, the boys were more exposed to maltreatment than the girls of the same age group as much literature supported that (Al Eissa and Almuneef 2010; Evans et al. 2008 ). That might be explained by the more tumultuous and rowdier nature of the boys than the girls. In disparity with the current study, Al-Eissa et al., in their study carried out in Saudi Arabia, reported that the females were commonly exposed to physical maltreatment than the males (AlEissa et al., 2015)(Al-Eissa et al., 2015). 
This discrepancy might be attributed to the different ages of the participants between the two studies; the study conducted in Saudi Arabia targeted the adolescent mainly. Another explanation is the more restrictions practiced over the adolescent females so, the time spent at home is mostly more than the males.

This argument supports the fact highlighted in the current study; most of the families don't practice isolated form violence. Instead, they combine both verbal and physical maltreatment forms (Hemenway et al., 1994).

\section{CONCLUSION}

Home is not always a safe environment; behind closed doors, many unfair maltreatments are inflicted on innocent children. Verbal and physical maltreatment are aggravated by the lockdown and quarantine measures associated with the COVID-19 pandemic. The forms of verbal and physical maltreatment didn't differ from those previously reported in the literature. The younger boys to younger parents are more vulnerable to physical maltreatment.

\section{RECOMMENDATION}

Based on the mentioned findings, it is recommended to pay more attention to the children's maltreatment issue, especially during a current pandemic crisis. Preventing child maltreatment, protecting the maltreated child by establishing hotline help calls, and supporting centers to track and follow such cases is necessary. Paternal monitoring and guidance counseling services could be facilitated during such extraordinary situations.

\section{REFERENCES}

Adinkrah, M. (2000): "Maternal infanticides in Fiji," Child Abuse \& Neglect, Elsevier, Vol. 24 No. 12, pp. 1543-1555.

Al-Dabaan, R., Newton, J.T. and Asimakopoulou, K. (2014):

"Knowledge, attitudes, and experience of dentists living in Saudi Arabia toward child abuse and neglect," Saudi Dental Journal.

Al-Eissa, M.A., AlBuhairan, F.S., Qayad, M., Saleheen, H., Runyan, D. and Almuneef, M. (2015): "Determining child maltreatment incidence in Saudi Arabia using the ICAST-CH: A pilot study," Child Abuse and Neglect, Vol. 42, pp. 174-182.

Allen-Ebrahimian, B. (2020): "China's Domestic Violence Epidemic," Retrieved on March, Vol. 26.

Almuneef, M. and Al-Eissa, M. (2011): "Preventing child abuse and neglect in Saudi Arabia: Are we ready," Annals of Saudi Medicine, Vol. 31 No. 6, pp. 635-640.

Alsehaimi, A. (2015): "The Nature of Domestic Violence against of Children in Saudi Arabia Systematic Literature Review," Journal of Psychological Abnormalities in Children, Vol. 04 No. 03, pp. 3-5.

Bangdiwala, S.I., Ramiro, L., Sadowski, L.S., Bordin, I.A.S., Hunter, W. and Shankar, V. (2004): "Intimate partner violence and the role of socioeconomic indicators in WorldSAFE communities in Chile, Egypt, India, and the Philippines.", Injury Control and Safety Promotion, Vol. 11 No. 2, pp. 101-109.

Boserup, B., McKenney, M. and Elkbuli, A. (2020): "Alarming trends in U.S. domestic violence during the COVID19 pandemic", American Journal of Emergency Medicine, Vol. 91 No. 20, pp. 3-5.

Bradbury-Jones, C. and Isham, L. (2020): "The pandemic paradox: The consequences of COVID-19 on domestic violence", Journal of Clinical Nursing, Vol. 19, pp. 1-3.

Brooks, S.K., Webster, R.K., Smith, L.E., Woodland, L., Wessely, S., Greenberg, N. and Rubin, G.J. (2020): "El impacto psicológico de la cuarentena y cómo reducirla: revisión rápida de las pruebas", Lancet, Vol. 
395, pp. 912-920.

Campbell, A.M. (2020): "An increasing risk of family violence during the Covid-19 pandemic: Strengthening community collaborations to save lives", Forensic Science International: Reports, Elsevier B.V., Vol. 2 No. April, p. 100089.

Cao, W., Fang, Z., Hou, G., Han, M., Xu, X., Dong, J. and Zheng, J. (2020): "The psychological impact of the COVID-19 epidemic on college students in China", Psychiatry Research, Elsevier, p. 112934.

Douglas, M., Katikireddi, S.V., Taulbut, M., McKee, M. and McCartney, G. (2020): "Mitigating the wider health effects of covid-19 pandemic response", The B.M.J., Vol. 369 No. April, pp. 1-6.

Elbendary radwan, reham, farrag, islam, farag, Hesham and Bayoumi, amani (2019), "A Retrospective Study of Child Deaths Among Cases Referred To the Egyptian Forensic Medicine Authority During the Period From January To December 2016". The Egyptian Journal of Forensic Sciences and Applied Toxicology, 19(4): 65-90.

Al Eissa, M., and Almuneef, M. (2010): "Child Abuse and Neglect in Saudi Arabia: Journey of recognition to implementation of national prevention strategies," Child Abuse and Neglect, Vol. 34 No. 1, pp. 28-33.

Van Gelder, N., Peterman, A., Potts, A., O'Donnell, M., Thompson, K., Shah, N. and Oertelt-Prigione, S. (2020): "COVID-19: Reducing the risk of infection might increase the risk of intimate partner violence", EClinicalMedicine, Elsevier Ltd, Vol. 21, p. 100348.

Graham-Harrison, E., Giuffrida, A., Smith, H. and Ford, L. (2020): "Lockdowns around the world bring a rise in domestic violence," The Guardian.

Gulati, G., and Kelly, B.D. (2020):
"Domestic violence against women and the COVID-19 pandemic: What is the role of psychiatry?", International Journal of Law and Psychiatry, Elsevier, Vol. 71 No. May p. 101594.

Guterman, N.B. (2008): “基因的改变NIH Public Access", Bone, Vol. 23 No. 1, pp. 1-7.

Hemenway, D., Solnick, S. and Carter, J. (1994): "Child-rearing violence," Child Abuse \& Neglect, Elsevier, Vol. 18 No. 12, pp. 1011-1020.

Hunter, W.M., Jain, D., Sadowski, L.S. and Sanhueza, A.I. (2000): "Risk factors for severe child discipline practices in rural India," Journal of Pediatric Psychology, Oxford University Press, Vol. 25 No. 6, pp. 435-447.

Kantor, G., Jasinski, J., Straus, M. and Hamby, S. (2014): "Measuring Physical and Psychological Maltreatment of Children with the Conflict Tactics Scales," Out of the Darkness: Contemporary Perspectives on Family Violence, pp. 119-135.

Karthikeyan, G., Mohanty, S.K. and Fouzi, A. (2000): "Child abuse: Report of three cases from Khamis Mushayt," Annals of Saudi Medicine, King Faisal Specialist Hospital and Research Centre, Vol. 20 No. 5-6, pp. 430-432.

Klevens, J., Bayón, M.C. and Sierra, M. (2000): "Risk factors and context of men who physically abuse in Bogota, Colombia," Child Abuse \& Neglect, Elsevier, Vol. 24 No. 3, pp. 323-332.

Krug, E.G., Mercy, J.A., Dahlberg, L.L., and Zwi, A.B. (2002): "The world report on violence and health," The Lancet, Elsevier, Vol. 360 No. 9339, pp. 1083-1088.

Liu, S., Yang, L., Zhang, C., Xiang, Y.-T., Liu, Z., Hu, S. and Zhang, B. (2020): "Online mental health services in China during the COVID-19 outbreak", The Lancet Psychiatry, Elsevier, Vol. 7 No. 4, pp. e17-e18.

Mazza, M., Marano, G., Lai, C., Janiri, L. and Sani, G. (2020): "Danger in 
danger: Interpersonal violence during COVID-19 quarantine", Psychiatry Research, Elsevier Ireland Ltd, Vol. 289 No. April, p. 113046.

Meinck, F., Steinert, J., Sethi, D., Gilbert, R., Bellis, M., Alink, L. and Baban,

A. (2016): "Measuring and monitoring national prevalence of child maltreatment: a practical handbook," The World Health Organisation.

Peterman, A., Potts, A., Donnell, M.O., Shah, N., Oertelt-prigione, S., Gelder, N. Van, Peterman, A., et al. (2020): "Working Paper 528 April 2020 Pandemics and Violence Against Women and Children", Center for Global Development, No. 528, p. 43.

Pro, P.D.F.C. (2002): "Child abuse and neglect by parents and other caregivers."

Ragamayi, M.P.S. (2020): "LEVEL OF FAMILY BONDING AMOND YOUNG ADULTS DURING NATIONAL LOCKDOWN DUE TO COVID-19", Purakala with ISSN 0971-2143 Is an UGC CARE Journal, Purakala, Vol. 31 No. 12, pp. 684-698.

Tang, C.S.-K. (1998): "The rate of physical child abuse in Chinese families: A community survey in Hong Kong," Child Abuse \& Neglect, Elsevier, Vol. 22 No. 5, pp. 381-391.

Usher, K., Bhullar, N., Durkin, J., Gyamfi, N. and Jackson, D. (2020): "Family violence and COVID-19:
Increased vulnerability and reduced options for support", International Journal of Mental Health Nursing, Wiley Online Library.

Wang, G., Zhang, Y., Zhao, J., Zhang, J. and Jiang, F. (2020): "Mitigate the effects of home confinement on children during the COVID-19 outbreak", The Lancet, Vol. 395 No. 10228, pp. 945-947.

Women, U.N. (2020): "COVID-19 and ending violence against women and girls", New York. https://www. unwomen. $\quad$ org//media/headquarters/attachments ....

World Health Organization. (2020): "Addressing Violence Against Children, Women and Older People During the Covid-19 Pandemic: Key Actions", No. June, pp. 1-7.

Youssef, R.M., Attia, M.S.E.D. and Kamel, M.I. (1998): "Children experiencing violence I: Parental use of corporal punishment," Child Abuse and Neglect, Vol. 22 No. 10, pp. 959973.

Zaghloul, Nancy, Hetta, Sherief and Ramadan, Nazih (2020), "MedicoLegal Relation between Children Abuse and Child Labor in Great Cairo Governorate, Egypt". The Egyptian Journal of Forensic Sciences and Applied Toxicology, 20(1): 81-91. 
تأثير الحظر المنزلي بسبب فيروس كورونا المستجد على العنف السلوكي لمقدمي الرعاية تجاه أطفالهم

أسماء فادي شريف أ، ب أب

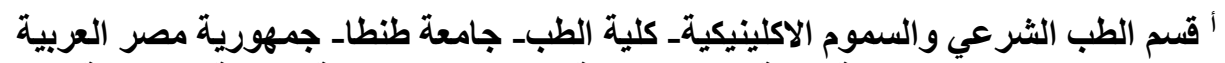

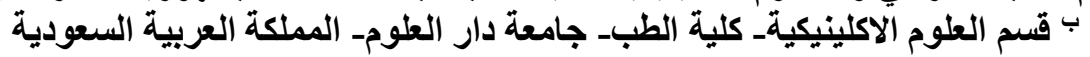

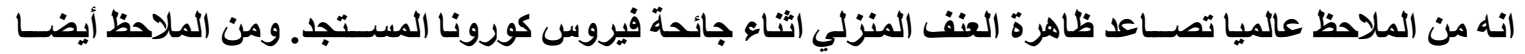

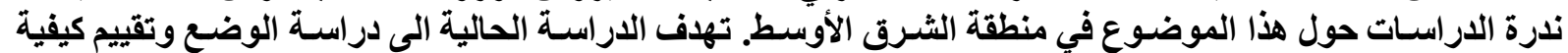

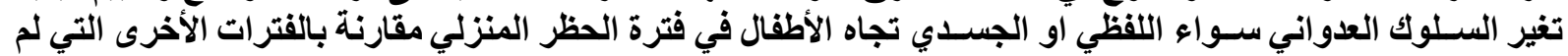

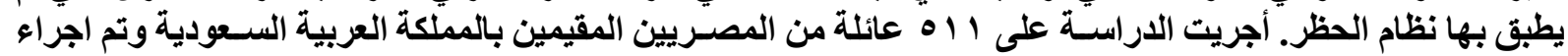

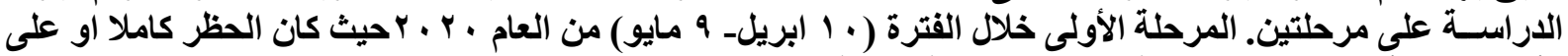

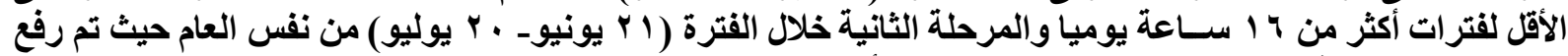

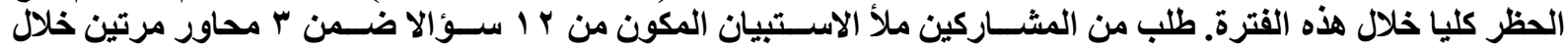

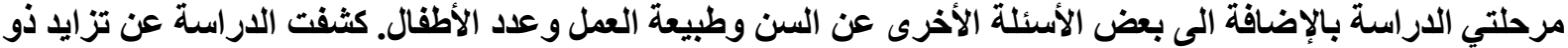

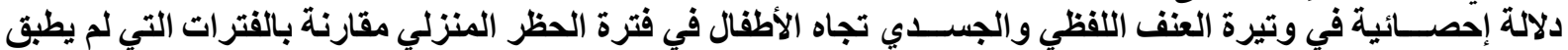

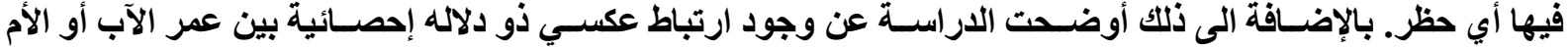

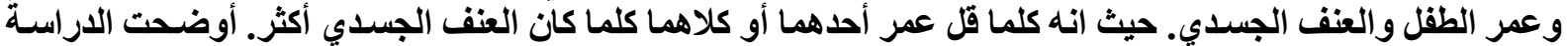

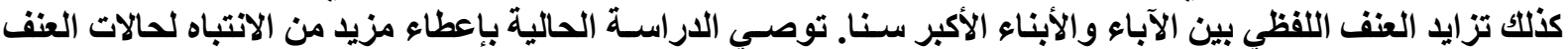

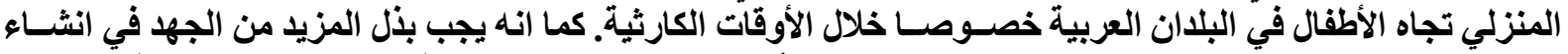

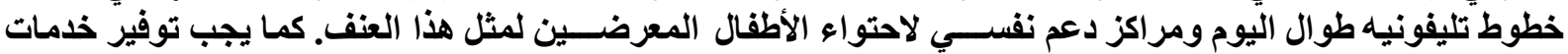

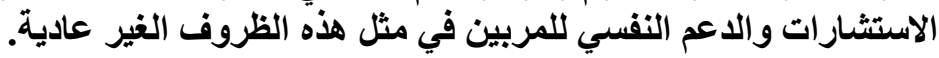

